4

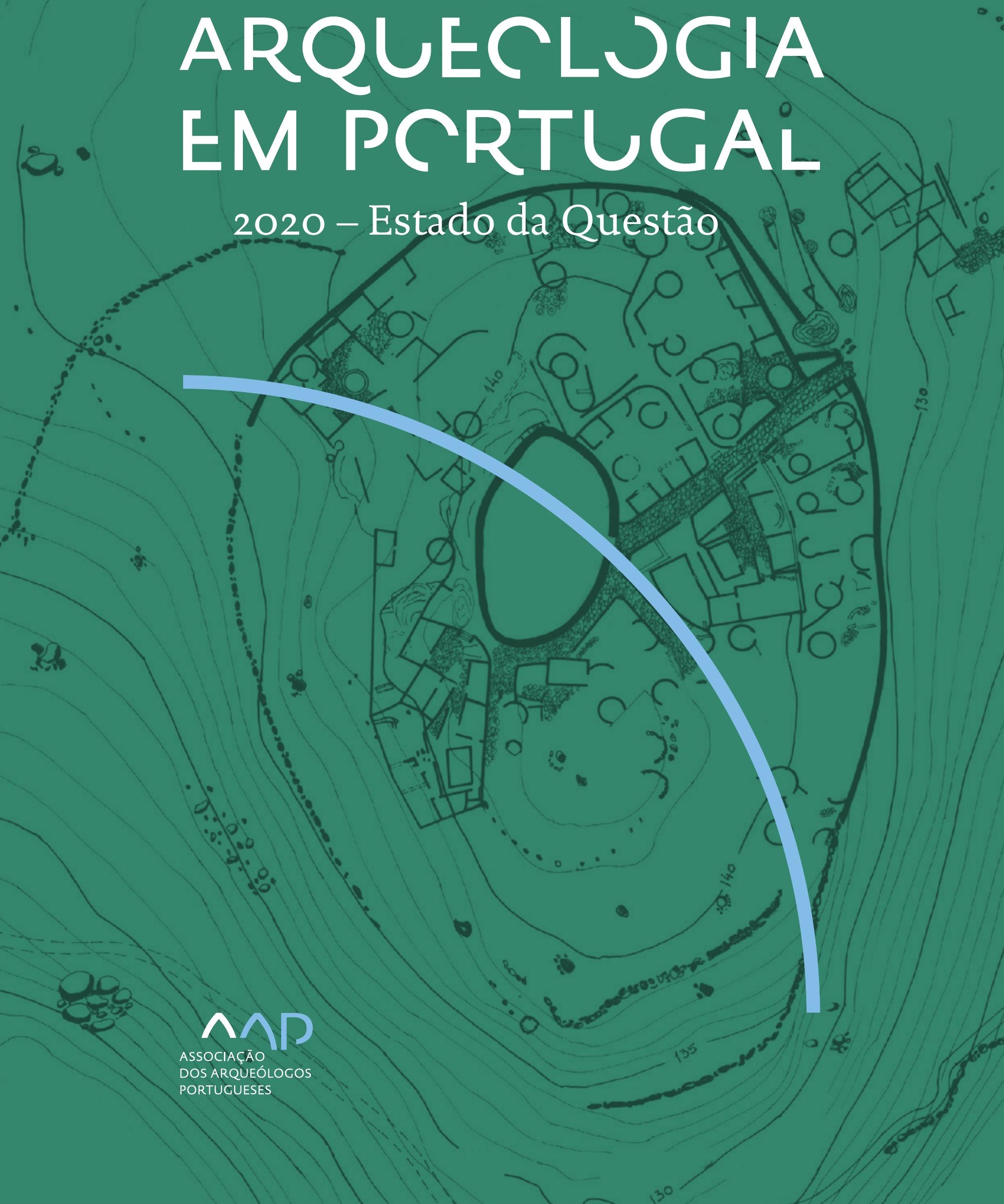


Coordenação editorial: José Morais Arnaud, César Neves e Andrea Martins Design gráfico: Flatland Design

AAP - ISBN: 978-972-9451-89-8

CITCEM - ISBN: 978-989-8970-25-1

Associação dos Arqueólogos Portugueses e CITCEM

Lisboa, 2020

O conteúdo dos artigos é da inteira responsabilidade dos autores. Sendo assim a Associação dos Arqueólogos Portugueses declina qualquer responsabilidade por eventuais equívocos ou questões de ordem ética e legal.

Desenho de capa:

Planta do castro de Monte Mozinho (Museu Municipal de Penafiel).

\section{$\hat{\wedge} \mathrm{P}$}

DOS ARQUEÓLOGOS PORTUGUESES

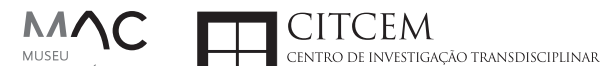
MUSEU
ARQUELLÓGICO
DO CARMO
U.PORTO

FLUP FACULDADE DE LETRAS
UNIVERSIDADE DO PORTO

Apoio

EC para a Ciência 


\section{Índice}

15 Prefácio

José Morais Arnaud

\section{Historiografia e Teoria}

17 Território, comunidade, memória e emoção: a contribuição da história da arqueologia (algumas primeiras e breves reflexões)

Ana Cristina Martins

25 Como descolonizar a arqueologia portuguesa?

Rui Gomes Coelho

41 Arqueologia e Modernidade: uma revisitação pessoal e breve de alguns aspetos da obra homónima de Julian Thomas de 2004

Vítor Oliveira Jorge

57 Dados para a História das Mulheres na Arqueologia portuguesa, dos finais do século XIX aos inícios do século XX: números, nomes e tabelas

Filipa Dimas / Mariana Diniz

73 Retractos da arqueologia portuguesa na imprensa: (in)visibilidades no feminino

Catarina Costeira / Elsa Luís

85 Arqueologia e Arqueólogos no Norte de Portugal Jacinta Bugalhão

101 Vieira Guimarães (1864-1939) e a arqueologia em Tomar: uma abordagem sobre o território e as gentes

João Amendoeira Peixoto / Ana Cristina Martins

115 Os memoráveis? A arqueologia algarvia na imprensa nacional e regional na presente centúria (2001-2019): características, visões do(s) passado(s) e a arqueologia

enquanto marca

Frederico Agosto / João Silva

129 A Evolução da Arqueologia Urbana e a Valorização Patrimonial no Barlavento Algarvio: Os casos de Portimão e Silves

Artur Mateus / Diogo Varandas / Rafael Boavida

\section{Gestão, Valorização e Salvaguarda do Património}

145 O Caderno Reivindicativo e as condições de trabalho em Arqueologia Miguel Rocha / Liliana Matias Carvalho / Regis Barbosa / Mauro Correia / Sara Simões / Jacinta Bugalhão / Sara Brito / Liliana Veríssimo Carvalho / Richard Peace / Pedro Peça / Cézer Santos

155 Os Estudos de Impacte Patrimonial como elemento para uma estratégia sustentável de minimização de impactes no âmbito de reconversões agrícolas Tiago do Pereiro

165 Salvaguarda de Património arqueológico em operações florestais: gestão e sensibilização Filipa Bragança / Gertrudes Zambujo / Sandra Lourenço / Belém Paiva / Carlos Banha / Frederico Tatá Regala / Helena Moura / Jacinta Bugalhão / João Marques / José Correia / Pedro Faria / Samuel Melro

179 Os valores do Património: uma investigação sobre os Sítios Pré-históricos de Arte Rupestre do Vale do Rio Côa e de Siega Verde José Paulo Francisco 
189 Conjugando recursos arqueológicos e naturais para potenciar as visitas ao Geoparque Litoral de Viana do Castelo (Noroeste de Portugal)

Hugo A. Sampaio / Ana M.S. Bettencourt / Susana Marinho / Ricardo Carvalhido

203 Áreas de Potencial Arqueológico na Região do Médio Tejo: Modelo Espacial Preditivo Rita Ferreira Anastácio / Ana Filipa Martins / Luiz Oosterbeek

223 Património Arqueológico e Gestão Territorial: O contributo da Arqueologia para a revisão do PDM de Avis

Ana Cristina Ribeiro

237 A coleção arqueológica do extinto Museu Municipal do Porto - Origens, Percursos e Estudos

Sónia Couto

251 Valpaços - uma nova carta arqueológica

Pedro Pereira / Maria de Fátima Casares Machado

263 Arqueologia na Cidade de Peniche

Adriano Constantino / Luís Rendeiro

273 Arqueologia Urbana: a cidade de Lagos como caso de Estudo Cátia Neto

285 Estratégias de promoção do património cultural subaquático nos Açores. O caso da ilha do Faial

José Luís Neto / José Bettencourt / Luís Borges / Pedro Parreira

297 Carta Arqueológica da Cidade Velha: Uma primeira abordagem

Jaylson Monteiro / Nireide Tavares / Sara da Veiga / Claudino Ramos / Edson Brito /

Carlos Carvalho / Francisco Moreira / Adalberto Tavares

311 Antropologia Virtual: novas metodologias para a análise morfológica e funcional Ricardo Miguel Godinho / Célia Gonçalves

\section{Didáctica da Arqueologia}

327 Como os projetos de Arqueologia podem contribuir para uma comunidade culturalmente mais consciente Alexandra Figueiredo / Claúdio Monteiro / Adolfo Silveira / Ricardo Lopes

337 Educação Patrimonial - Um cidadão esclarecido é um cidadão ativo! Ana Paula Almeida

351 A aproximação da Arqueologia à sala de aula: um caso de estudo no $3^{\circ}$ ciclo do Ensino Básico Luís Serrão Gil

363 Arqueologia 3.o - Pensar e comunicar a Arqueologia para um futuro sustentável Mónica Rolo

377 “Conversa de Arqueólogos" - Divulgar a Arqueologia em tempos de Pandemia Diogo Teixeira Dias

389 Escola Profissional de Arqueologia: desafios e oportunidades Susana Nunes / Dulcineia Pinto / Júlia Silva / Ana Mascarenhas

399 Os Museus de Arqueologia e os Jovens: a oferta educativa para o público adolescente Beatriz Correia Barata / Leonor Medeiros

411 O museu universitário como mediador entre a ciência e a sociedade: o exemplo da secção de arqueologia no Museu de História Natural e da Ciência da Universidade do Porto (MHNC-UP)

Rita Gaspar 
421 Museu de Lanifícios: Real Fábrica de Panos. Atividades no âmbito da Arqueologia Beatriz Correia Barata / Rita Salvado

427 Arqueologia Pública e o caso da localidade da Mata (Torres Novas) Cláudia Manso / Ana Rita Ferreira / Cristiana Ferreira / Vanessa Cardoso Antunes

431 Do sítio arqueológico ao museu: um percurso (também) didático Lídia Fernandes

447 Estão todos convidados para a Festa! E para dançar também... O projecto do Serviço Educativo do Museu Arqueológico do Carmo na $5^{\underline{a}}$ Edição da Festa da Arqueologia Rita Pires dos Santos

459 O “Clã de Carenque”, um projeto didático de arqueologia Eduardo Gonzalez Rocha

469 Mediação cultural: peixe que puxa carroça nas Ruínas Romanas de Troia Inês Vaz Pinto / Ana Patrícia Magalhães / Patrícia Brum / Filipa Santos

481 Didática Arqueológica, experiências do Projeto Mértola Vila Museu Maria de Fátima Palma / Clara Rodrigues / Susana Gómez / Lígia Rafael

\section{Arte Rupestre}

497 Os inventários de arte rupestre em Portugal Mila Simões de Abreu

513 O projeto FIRST-ART - conservação, documentação e gestão das primeiras manifestações de arte rupestre no Sudoeste da Península Ibérica: as grutas do Escoural e Maltravieso Sara Garcês / Hipólito Collado / José Julio García Arranz / Luiz Oosterbeek / António Carlos Silva / Pierluigi Rosina / Hugo Gomes / Anabela Borralheiro Pereira / George Nash / Esmeralda Gomes / Nelson Almeida / Carlos Carpetudo

523 Trabalhos de documentação de arte paleolítica realizados no âmbito do projeto PalæoCôa André Tomás Santos / António Fernando Barbosa / Luís Luís / Marcelo Silvestre / Thierry Aubry

537 Imagens fantasmagóricas, silhuetas elusivas: as figuras humanas na arte do Paleolítico Superior da região do Côa Mário Reis

$55^{1}$ Os motivos zoomórficos representados nas placas de tear de Vila Nova de São Pedro (Azambuja, Portugal) Andrea Martins / César Neves / José M. Arnaud / Mariana Diniz

571 Arte Rupestre do Monte de Góios (Lanhelas, Caminha). Síntese dos resultados dos trabalhos efectuados em 2007-2009 Mário Varela Gomes

599 Gravuras rupestres de barquiformes no Monte de S. Romão, Guimarães, Noroeste de Portugal Daniela Cardoso

613 Círculos segmentados gravados na Bacia do Rio Lima (Noroeste de Portugal): contributos para o seu estudo Diogo Marinho / Ana M.S. Bettencourt / Hugo Aluai Sampaio

631 Equídeos gravados no curso inferior do Rio Mouro, Monção (NW Portugal). Análise preliminar Coutinho, L.M. / Bettencourt, A.M.S / Sampaio, Hugo A.S

645 Paletas na Arte Rupestre do Noroeste de Portugal. Inventário preliminar Bruna Sousa Afonso / Ana M. S. Bettencourt / Hugo A. Sampaio 


\section{Pré-História}

661 O projeto Miño/Minho: balanço de quatro anos de trabalhos arqueológicos Sérgio Monteiro-Rodrigues / João Pedro Cunha-Ribeiro / Eduardo Méndez-Quintas / Carlos Ferreira / Pedro Xavier / José Meireles / Alberto Gomes / Manuel Santonja / Alfredo Pérez-González

677 A ocupação paleolítica da margem esquerda do Baixo Minho: a indústria lítica do sítio de Pedreiras 2 (Monção, Portugal) e a sua integração no contexto regional Carlos Ferreira / João Pedro Cunha-Ribeiro / Sérgio Monteiro-Rodrigues / Eduardo Méndez-Quintas / Pedro Xavier / José Meireles / Alberto Gomes / Manuel Santonja / Alfredo Pérez-González

693 O sítio acheulense do Plistocénico médio da Gruta da Aroeira Joan Daura / Montserrat Sanz / Filipa Rodrigues / Pedro Souto / João Zilhão

703 As sociedades neandertais no Barlavento algarvio: modelos preditivos com recurso aos SIG

Daniela Maio

715 A utilização de quartzo durante o Paleolítico Superior no território dos vales dos rios Vouga e Côa

Cristina Gameiro / Thierry Aubry / Bárbara Costa / Sérgio Gomes / Luís Luís / Carmen Manzano / André Tomás Santos

733 Uma perspetiva diacrónica da ocupação do concheiro do Cabeço da Amoreira (Muge, Portugal) a partir da tecnologia lítica Joana Belmiro / João Cascalheira / Célia Gonçalves

745 Novos dados sobre a Pré-história Antiga no concelho de Palmela. A intervenção arqueológica no sítio do Poceirão I

Michelle Teixeira Santos

757 Problemas em torno de Datas Absolutas Pré-Históricas no Norte do Alentejo Jorge de Oliveira

771 Povoamento pré-histórico nas áreas montanhosas do NO de Portugal: o Abrigo 1 de Vale de Cerdeira Pedro Xavier / José Meireles / Carlos Alves

783 Apreciação do povoamento do Neolítico Inicial na Baixa Bacia do Douro. A Lavra I (Serra da Aboboreira) como caso de estudo Maria de Jesus Sanches

797 O Processo de Neolitização na Plataforma do Mondego: os dados do Sector C do Outeiro dos Castelos de Beijós (Carregal do Sal)

João Carlos de Senna-Martinez / José Manuel Quintã Ventura / Andreia Carvalho / Cíntia Maurício

823 Novos trabalhos na Lapa da Bugalheira (Almonda, Torres Novas) Filipa Rodrigues / Pedro Souto / Artur Ferreira / Alexandre Varanda / Luís Gomes / Helena Gomes / João Zilhão

837 A pedra polida e afeiçoada do sítio do Neolítico médio da Moita do Ourives (Benavente, Portugal)

César Neves

857 Casal do Outeiro (Encarnação, Mafra): novos contributos para o conhecimento do povoamento do Neolítico final na Península de Lisboa.

Cátia Delicado / Carlos Maneira e Costa / Marta Miranda / Ana Catarina Sousa

873 Stresse infantil, morbilidade e mortalidade no sítio arqueológico do Neolítico Final/ Calcolítico ( $4^{\circ}$ e $3^{\circ}$ milénio a.C.) do Monte do Carrascal 2 (Ferreira do Alentejo, Beja) Liliana Matias de Carvalho / Sofia N. Wasterlain 
885 Come together: O Conjunto Megalítico das Motas (Monção, Viana do Castelo) e as expressões Campaniformes do Alto Minho Ana Catarina Basílio / Rui Ramos

899 Trabalhos arqueológicos no sítio Calcolítico da Pedreira do Poio Carla Magalhães / João Muralha / Mário Reis / António Batarda Fernandes

913 O sítio arqueológico de Castanheiro do Vento. Da arquitectura do sítio à arquitectura de um território João Muralha Cardoso

925 Estudo zooarqueológico das faunas do Calcolítico final de Vila Nova de São Pedro (Azambuja, Portugal): Campanhas de 2017 e 2018 Cleia Detry / Ana Catarina Francisco / Mariana Diniz / Andrea Martins / César Neves / José Morais Arnaud

943 As faunas depositadas no Museu Arqueológico do Carmo provenientes de Vila Nova de São Pedro (Azambuja): as campanhas de 1937 a 1967 Ana Catarina Francisco / Cleia Detry / César Neves / Andrea Martins / Mariana Diniz / José Morais Arnaud

959 Análise funcional de material lítico em sílex do castro de Vila Nova de S. Pedro (Azambuja, Portugal): uma primeira abordagem Rafael Lima

971 O recinto da Folha do Ouro 1 (Serpa) no contexto dos recintos de fossos calcolíticos alentejanos

António Carlos Valera / Tiago do Pereiro / Pedro Valério / António M. Monge Soares

\section{Proto-História}

987 Produção de sal marinho na Idade do Bronze do noroeste Português. Alguns dados para uma reflexão

Ana M. S. Bettencourt / Sara Luz / Nuno Oliveira / Pedro P. Simões / Maria Isabel C. Alves / Emílio Abad-Vidal

1001 A estátua-menir do Pedrão ou de São Bartolomeu do Mar (Esposende, noroeste de Portugal) no contexto arqueológico da fachada costeira de entre os rios Neiva e Cávado Ana M. S. Bettencourt / Manuel Santos-Estévez / Pedro Pimenta Simões / Luís Gonçalves

1015 O Castro do Muro (Vandoma/Baltar, Paredes) - notas para uma biografia de ocupação da Idade do Bronze à Idade Média

Maria Antónia D. Silva / Ana M. S. Bettencourt / António Manuel S. P. Silva / Natália Félix

1031 Do Bronze Final à Idade Média - continuidades e hiatos na ocupação de Povoados em Oliveira de Azeméis João Tiago Tavares / Adriaan de Man

1041 As faunas do final da Idade do Bronze no Sul de Portugal: leituras desde o Outeiro do Circo (Beja)

Nelson J. Almeida / Íris Dias / Cleia Detry / Eduardo Porfírio / Miguel Serra

1055 A Espada do Monte das Oliveiras (Serpa) - uma arma do Bronze Pleno do Sudoeste Rui M. G. Monge Soares / Pedro Valério / Mariana Nabais / António M. Monge Soares

1065 São Julião da Branca (Albergaria-a-Velha) - Investigação e valorização de um povoado do Bronze Final

António Manuel S. P. Silva / Paulo A. P. Lemos / Sara Almeida e Silva / Edite Martins de Sá

1083 Do castro de S. João ao Mosteiro de Santa Clara: notícia de uma intervenção arqueológica, em Vila do Conde Rui Pinheiro 
1095 O castro de Ovil (Espinho), um quarto de século de investigação - resultados e questões em aberto

Jorge Fernando Salvador / António Manuel S. P. Silva

1111 O Castro de Salreu (Estarreja), um povoado proto-histórico no litoral do Entre Douro e Vouga

Sara Almeida e Silva / António Manuel S. P. Silva / Paulo A. P. Lemos / Edite Martins de Sá

1127 Castro de Nossa Senhora das Necessidades (Sernancelhe): uma primeira análise artefactual Telma Susana O. Ribeiro

${ }_{1141}$ A cividade de Bagunte. O estado atual da investigação Pedro Brochado de Almeida

1153 Zoomorfos na cerâmica da Idade do Ferro no NW Peninsular: inventário, cronologias e significado Nuno Oliveira / Cristina Seoane

1163 Vasos gregos em Portugal: diferentes maneiras de contar a história do intercâmbio cultural na Idade do Ferro

Daniela Ferreira

1175 Os exotica da necrópole da Idade do Ferro do Olival do Senhor dos Mártires (Alcácer do Sal) no seu contexto regional

Francisco B. Gomes

\section{Antiguidade Clássica e Tardia}

1191 O uso de madeira como combustível no sítio da Quinta de Crestelos (Baixo Sabor): da Idade do Ferro à Romanização Filipe Vaz / João Tereso / Sérgio Simões Pereira / José Sastre / Javier Larrazabal Galarza / Susana Cosme / José António Pereira / Israel Espi

1207 Cultivos de Época Romana no Baixo Sabor: continuidade em tempos de mudança? João Pedro Tereso / Sérgio Simões Pereira / Filipe Santos / Luís Seabra / Filipe Vaz

1221 A casa romana na Hispânia: aplicação dos modelos itálicos nas províncias ibéricas Fernanda Magalhães / Diego Machado / Manuela Martins

1235 As pinturas murais romanas da Rua General Sousa Machado, n. ${ }^{5}$ 1, Chaves José Carvalho

1243 Trás do Castelo (Vale de Mir, Pegarinhos, Alijó) - Uma exploração agrícola romana do Douro

Tony Silvino / Pedro Pereira

1255 A sequência de ocupação no quadrante sudeste de Bracara Augusta: as transformações de uma unidade doméstica Lara Fernandes / Manuela Martins

1263 Os Mosaicos com decoração geométrica e geométrico-vegetalista dos sítios arqueológicos da área do Conuentus Bracaraugustanus. Novas abordagens quanto à conservação, restauro, decoração e datação Maria de Fátima Abraços / Licínia Wrench

1277 “Casa Romana” do Castro de São Domingos (Cristelos, Lousada): Escavação, Estudo e Musealização Paulo André de P. Lemos

1291 A arqueobotânica no Castro de Guifões (Matosinhos, Noroeste de Portugal): O primeiro estudo carpológico

Luís Seabra / Andreia Arezes / Catarina Magalhães / José Varela / João Pedro Tereso 
1305 Um Horreum Augustano na Foz do Douro (Monte do Castelo de Gaia, Vila Nova de Gaia) Rui Ramos

1311 Ponderais romanos na Lusitânia: padrões, formas, materiais e contextos de utilização Diego Barrios Rodríguez

1323 Um almofariz centro-itálico na foz do Mondego

Marco Penajoia

1335 Estruturas romanas de Carnide - Lisboa Luísa Batalha / Mário Monteiro / Guilherme Cardoso

1347 O contexto funerário do sector da "necrópole NO" da Rua das Portas de S. Antão (Lisboa): o espaço, os artefactos, os indivíduos e a sua interconectividade na interpretação do passado Sílvia Loja, José Carlos Quaresma, Nelson Cabaço, Marina Lourenço, Sílvia Casimiro, Rodrigo Banha da Silva, Francisca Alves-Cardoso

${ }_{1361}$ Povoamento em época Romana na Amadora - resultados de um projeto pluridisciplinar Gisela Encarnação / Vanessa Dias

1371 A Arquitectura Residencial em Mirobriga (Santiago do Cacém): contributo a partir de um estudo de caso Filipe Sousa / Catarina Felício

${ }_{1385}$ O fim do ciclo. Saneamento e gestão de resíduos nos edifícios termais de Mirobriga (Santiago do Cacém)

Catarina Felício / Filipe Sousa

1399 Balsa, Topografia e Urbanismo de uma Cidade Portuária Vítor Silva Dias / João Pedro Bernardes / Celso Candeias / Cristina Tété Garcia

1413 No Largo das Mouras Velhas em Faro (2017): novas evidências da necrópole norte de Ossonoba e da sua ocupação medieval Ricardo Costeira da Silva / Paulo Botelho / Fernando Santos / Liliana Nunes

1429 Instrumentos de pesca recuperados numa fábrica de salga em Ossonoba (Faro) Inês Rasteiro / Ricardo Costeira da Silva / Paulo Botelho

1439 A Necrópole Romana do Eirô, Duas Igrejas (Penafiel): intervenção arqueológica de 2016 Laura Sousa / Teresa Soeiro

1457 Ritual, descarte ou afetividade? A presença de Canis lupus familiaris na Necrópole Noroeste de Olisipo (Lisboa)

Beatriz Calapez Santos / Sofia Simões Pereira / Rodrigo Banha da Silva / Sílvia Casimiro / Cleia Detry / Francisca Alves Cardoso

1467 Dinâmicas económicas em Bracara na Antiguidade Tardia Diego Machado / Manuela Martins / Fernanda Magalhães / Natália Botica

1479 Cerâmicas e Vidros da Antiguidade Tardia do Edifício sob a Igreja do Bom Jesus (Vila Nova de Gaia) Joaquim Filipe Ramos

1493 Novos contributos para a topografia histórica de Mértola no período romano e na Antiguidade Tardia Virgílio Lopes

\section{8. Época Medieval}

1511 Cerâmicas islâmicas no Garb setentrional "português": algumas evidências e incógnitas Constança dos Santos / Helena Catarino / Susana Gómez / Maria José Gonçalves / Isabel Inácio / Gonçalo Lopes / Jacinta Bugalhão / Sandra Cavaco / Jaquelina Covaneiro / Isabel Cristina Fernandes / Ana Sofia Gomes 
1525 Contributo para o conhecimento da cosmética islâmica, em Silves, durante a Idade Média Rosa Varela Gomes

1537 Yábura e o seu território - uma análise histórico-arqueológica de Évora entre os séculos VIII-XII José Rui Santos

1547 A encosta sul do Castelo de Palmela - resultados preliminares da escavação arqueológica Luís Filipe Pereira / Michelle Teixeira Santos

1559 A igreja de São Lourenço (Mouraria, Lisboa): um conjunto de silos e de cerâmica medieval islâmica

Andreia Filipa Moreira Rodrigues

1571 O registo material de movimentações populacionais no Médio Tejo, durante os séculos XII-XIII. Dois casos de "sunken featured buildings", nos concelhos de Cartaxo e Torres Novas Marco Liberato / Helena Santos / Nuno Santos

1585 O nordeste transmontano nos alvores da Idade média. Notas para reflexão Ana Maria da Costa Oliveira

1601 Sepulturas escavadas na rocha do Norte de Portugal e do Vale do Douro: primeiros resultados do Projecto SER-NPVD

Mário Jorge Barroca / César Guedes / Andreia Arezes / Ana Maria Oliveira

1619 "Portucalem Castrum Novum" entre o Mediterrâneo e o Atlântico: o estudo dos materiais cerâmicos alto-medievais do arqueossítio da rua de D. Hugo, nํ. 5 (Porto) João Luís Veloso

1627 A Alta Idade Média na fronteira de Lafões: notas preliminares sobre a Arqueologia no Concelho de Vouzela

Manuel Luís Real / Catarina Tente

1641 Um conjunto cerâmico medieval fora de portas: um breve testemunho aveirense Susana Temudo

${ }_{1651}$ Os Lóios do Porto: uma perspetiva integrada no panorama funerário da Baixa Idade Média à Época Moderna em meios urbanos em Portugal

Ana Lema Seabra

1659 O Caminho Português Interior de Santiago como eixo viário na Idade Média Pedro Azevedo

1665 Morfologia Urbana: Um exercício em torno do Castelo de Ourém André Donas-Botto / Jaqueline Pereira

1677 Intervenção arqueológica na Rua Marquês de Pombal/Largo do Espírito Santo (Bucelas, Loures)

Florbela Estêvão / Nathalie Antunes-Ferreira / Dário Ramos Neves / Inês Lisboa

1691 O Cemitério Medieval do Poço do Borratém e a espacialidade funerária na cidade de Lisboa Inês Belém / Vanessa Filipe / Vasco Noronha Vieira / Sónia Ferro / Rodrigo Banha da Silva

1705 Um Espaço Funerário Conventual do séc. XV em Lisboa: o caso do Convento de São Domingos da Cidade Sérgio Pedroso / Sílvia Casimiro / Rodrigo Banha da Silva / Francisca Alves Cardoso

\section{9. Época Moderna e Contemporânea}

1721 Arqueologia Moderna em Portugal: algumas reflexões críticas em torno da quantificação de conjuntos cerâmicos e suas inferências históricas e antropológicas Rodrigo Banha da Silva / André Bargão / Sara da Cruz Ferreira

1733 Faianças de dois contextos entre os finais do século XVI e XVIII do Palácio dos Condes de Penafiel, Lisboa

Martim Lopes / Tomás Mesquita 
1747 Um perfil de consumo do século XVIII na foz do Tejo: O caso do Mercado da Ribeira, Lisboa Sara da Cruz Ferreira / Rodrigo Banha da Silva / André Bargão

1761 Os Cachimbos dos Séculos XVII e XVIII do Palácio Mesquitela e Convento dos Inglesinhos (Lisboa)

Inês Simão / Marina Pinto / João Pimenta / Sara da Cruz Ferreira / André Bargão / Rodrigo Banha da Silva

1775 "Tomar os fumos da erua que chamão em Portugal erua sancta». Estudo de Cachimbos provenientes da Rua do Terreiro do Trigo, Lisboa

Miguel Martins de Sousa / José Pedro Henriques / Vanessa Galiza Filipe

1787 Cachimbos de Barro Caulínitico da Sé da Cidade Velha (República de Cabo Verde)

Rodrigo Banha da Silva / João Pimenta / Clementino Amaro

1801 Algumas considerações sobre espólio não cerâmico recuperado no Largo de Jesus (Lisboa) Carlos Boavida

1815 Adereços de vidro, dos séculos XVI-XVIII, procedentes do antigo Convento de Santana de Lisboa (anéis, braceletes e contas)

Joana Gonçalves / Rosa Varela Gomes / Mário Varela Gomes

1837 Da ostentação, luxo e poder à simplicidade do uso quotidiano: arqueologia e simbologia de joias e adornos da Idade Moderna Portuguesa Jéssica Iglésias

1849 Os amuletos em Portugal - dos objetos às superstições: o coral vermelho Alexandra Vieira

1865 Cerâmicas de Vila Franca de Xira nos séculos XV e XVI Eva Pires

1879 «Não passa por teu o que me pertence». Marcas de individualização associadas a faianças do Convento de Nossa Senhora de Aracoeli, Alcácer do Sal Catarina Parreira / Íris Fragoso / Miguel Martins de Sousa

1891 Cerâmica de Leiria: alguns focos de produção

Jaqueline Pereira / André Donas-Botto

1901 Os Fornos na Rua da Biquinha, em Óbidos Hugo Silva / Filipe Oliveira

1909 A casa de Pêro Fernandes, contador dos contos de D. Manuel I: o sítio arqueológico da Silha do Alferes, Seixal (século XVI) Mariana Nunes Ferreira

1921 O Alto da Vigia (Sintra) e a vigilância e defesa da costa Alexandre Gonçalves / Sandra Santos

1937 O contexto da torre sineira da Igreja de Santa Maria de Loures Paulo Calaveira / Martim Lopes

1949 A Necrópole do Hospital Militar do Castelo de São Jorge e as práticas funerárias na Lisboa de Época Moderna Susana Henriques / Liliana Matias de Carvalho / Ana Amarante / Sofia N. Wasterlain

1963 SAND - Sarilhos Grandes Entre dois Mundos: o adro da Igreja e a Paleobiologia dos ossos humanos recuperados

Paula Alves Pereira / Roger Lee Jesus / Bruno M. Magalhães

1975 Expansão urbana da vila de Cascais no século XVII e XVIII: a intervenção arqueológica na Rua da Vitória no 15 a 17

Tiago Pereira / Vanessa Filipe

1987 Novos dados para o conhecimento do Urbanismo de Faro em época Moderna Ana Rosa 
1995 Um exemplo de Arqueologia Urbana em Alcoutim: o Antigo Edifício dos CTT Marco Fernandes / Marta Dias / Alexandra Gradim / Virgílio Lopes / Susana Gómez Martínez

2007 Palácio dos Ferrazes (Rua das Flores/Rua da Vitória, Porto): a cocheira de Domingos Oliveira Maia

Francisco Raimundo

2021 As muitas vidas de um edifício urbano: História, Arqueologia e Antropologia no antigo Recreatório Paroquial de Penafiel Helena Bernardo / Jorge Sampaio / Marta Borges

2035 O convento de Nossa Senhora da Esperança de Ponta Delgada: o contributo da arqueologia para o conhecimento de um monumento identitário João Gonçalves Araújo / N’Zinga Oliveira

2047 Arqueologia na ilha do Corvo... em busca da capela de Nossa Senhora do Rosário Tânia Manuel Casimiro / José Luís Neto / Luís Borges / Pedro Parreira

2059 Perdidos à vista da Costa. Trabalhos arqueológicos subaquáticos na Barra do Tejo Jorge Freire / José Bettencourt / Augusto Salgado

2071 Arqueologia marítima em Cabo Verde: enquadramento e primeiros resultados do projecto CONCHA

José Bettencourt / Adilson Dias / Carlos Lima / Christelle Chouzenoux / Cristóvão Fonseca / Dúnia Pereira / Gonçalo Lopes / Inês Coelho / Jaylson Monteiro / José Lima / Maria Eugénia Alves / Patrícia Carvalho / Tiago Silva

2085 Trabalhos arqueológicos na Cidade Velha (Ribeira Grande de Santiago, Cabo Verde): reflexões sobre um projecto de investigação e divulgação patrimonial André Teixeira / Jaylson Monteiro / Mariana Mateus / Nireide Tavares / Cristovão Fonseca / Gonçalo C. Lopes / Joana Bento Torres / Dúnia Pereira / André Bargão / Aurélie Mayer / Bruno Zélie / Carlos Lima / Christelle Chouzenoux / Inês Henriques / Inês Pinto Coelho / José Lima / Patrícia Carvalho / Tiago Silva

2103 A antiga fortificação de Quelba / Khor Kalba (E.A.U.). Resultados de quatro campanhas de escavações, problemáticas e perspectivas futuras Rui Carita / Rosa Varela Gomes / Mário Varela Gomes / Kamyar Kamyad

2123 Colónias para homens novos: arqueologia da colonização agrária fascista no noroeste ibérico Xurxo Ayán Vila / José Mạ . Señorán Martín 


\title{
FAIANÇAS DE DOIS CONTEXTOS ENTRE OS FINAIS DO SÉCULO XVI E XVIII DO PALÁCIO DOS CONDES DE PENAFIEL, LISBOA
}

\author{
Martim Lopes ${ }^{1}$, Tomás Mesquita ${ }^{2}$
}

\begin{abstract}
RESUMO
O Palácio dos Condes de Penafiel, em Lisboa, foi alvo de intervenções arqueológicas entre 1992 e 1993, nas quais foram exumados três contextos de Época Moderna, entre os séculos XVI e XVIII (1755), quando está documentada a destruição do edifício prévio ao actual palácio dos Condes de Penafiel.

Os autores propõem-se analisar o espólio de faiança europeia proveniente dos dois contextos mais antigos, associados à desativação de uma conduta baixo-medieval (final do século XVI-XVII) e a edificação da primitiva unidade habitacional ( $1^{\circ}$ quartel do século XVI) que colapsa em 1755, onde foram recolhidas cerâmicas utilizadas na construção do edifício.

Palavras-chave: Faiança Portuguesa, Séculos XVI-XVIII, Majólica, Belarminos.
\end{abstract}

\begin{abstract}
The Palace of Condes de Penafiel, in Lisbon, was archaeological interventioned between 1992-1993, in which were recovered three contexts of historical archaeology, datable between the XVI century and the XVIII century, when is documented the collapse of the previous to the actual palace, during the 1755 earthquake.

The authors analyse the European faience recovered from the two oldest contexts (XVI-XVII century), associated to the deactivation of a medieval drain and the primitive edification of the building ( $1^{\text {st }}$ quarter of XVI century), which is destroyed in 1755 , where were collected ceramics reused within the walls.
\end{abstract}

Keywords: Portuguese Faience, XVI-XVIII Centuries, Maiolica, Belarmine.

\section{INTRODUÇÃO}

Os jardins do Palácio dos Condes de Penafiel estão situados numa das encostas do Castelo de São Jorge, no cruzamento da Rua de Martim Alho, o Largo do Correio Velho, a Rua de S. Mamede ao Caldas e a Calçada do Correio velho, tendo sido efectuada uma intervenção entre o ano de 1992 e 1993 pela equipa municipal, sob a direção de António Dias Diogo (Bargão, Ferreira e Silva, 2017, p.1781), estando o espaço actualmente ocupado com a sede da CPLP em Lisboa.

Esta área corresponde a uma edificação que remonta à reconstrução da cidade de Lisboa após os danos causados pelo terramoto de 1 de Novembro de 1755, sendo a datação da construção desta estrutura apontada para o período entre 1770 e 1773.

De acordo com o tombo pombalino, as unidades habitacionais prévias a 1770, exumadas no decorrer dos trabalhos, pertenceriam a D. Luís de Portugal (habitação Sul) e ao Padre João de Sequeira (habitação Norte) (Bargão, Ferreira e Silva, 2017, p. 1784). Já em 1650 é visível na planta de João Nunes Tinoco os contornos correspondentes às duas habitações, podendo ser recuadas as referências até à segunda metade do século XVI, através da iconografia de Bráunio, onde já está representado o quarteirão em causa (Bargão, Ferreira e Silva, 2017, p. 1784).

\footnotetext{
1. NOVA-FCSH; martimafonsorl@sapo.pt

2. ISCTE-IUL; tomasmmesquita@gmail.com
} 
No respeitante às condutas, estas estariam ainda em uso no século XVIII, ainda que a sua altura máxima de 1,30 m estivesse colmatado em mais de o,70 m por várias unidades, com profuso material cerâmico datável às primeiras décadas do século XVI, que sugerem o seu deficiente planeamento e falha de manutenção no curto prazo. Esta conduta, está referenciada no Livro dos Pregos, com uma datação de 1524 a 1545, onde se referencia a posse do espaço por Dona Catarina, denominado como as casas de Dona Catarina (Bargão, Ferreira e Silva, 2017, p. 1784-1785). Esta proprietária poderá tratar-se da Rainha D. Catarina de Áustria, ou de Habsburgo, casada com D. João III em 1524, situação que é coeva com a arquitectura (localização, área, saneamento e qualidade do edificado) exumada pela intervenção arqueológica. (Bargão, Ferreira e Silva, 2017, p. 1786).

Quanto aos materiais de Época Moderna, são conhecidos até ao momento informações parciais, com a publicação de algumas peças isoladas, do conjunto de porcelana (Henriques, 2012, p. 919-932), um jarro de cerâmica comum brunida, enquadrado entre os séculos XV-XVI (Silva e Ferreira, 2015, p. 134), e um conjunto de 866 azulejos hispano-mouriscos (Bargão, Ferreira e Silva, 2017, p. 1781-1782).

\section{CONTEXTO DA INTERVENÇÃO ARQUEOLÓGICA}

Em 1991, a transferência do Ministério das Obras Públicas, do Terreiro do Paço para a zona da Colina do Castelo, implicou a adaptação de um conjunto de imóveis situados entre as ruas de São Mamede, das Pedras Negras, a Travessa do Almada e a Calçada do Correio Velho. Os trabalhos arqueológicos, iniciaram-se em consequência da deteção de afetação do subsolo, provocada pela abertura de sondagens geotécnicas nos três edifícios contíguos com a Travessa do Almada (Guimarães, Silva, 2017, p. 1280).

Posto isto, aquando do inicio dos trabalhos no Palácio dos Condes de Penafiel, para a sua adaptação a sede do Ministério das Obras Públicas, a necessidade da construção de um piso de parqueamento subterrâneo no espaço do jardim, convergiu na execução de trabalhos arqueológicos com o consentimento do extinto Departamento de Arqueologia do Instituto Português do Património Cultural (Guimarães, Silva, 2017, p. 1280), sendo que a instalação dos organismos no novo espaço resultou num maior impacte no local onde se encontrava o jardim (Bargão, Ferreira e Silva, 2017, p. 1782).

A intervenção ficou a cargo do já extinto GTTRL (Gabinete de trabalho do Teatro Romano de Lisboa), extinto em 1998, e onde permaneceram todos os registos da escavação (Bargão, Ferreira e Silva, 2017, p.1782), razão pela qual a única análise que é possível elaborar quanto à estratigrafia é somente a que se consiga deduzir dos registos que existem de inventário, onde se identifica as quadrículas e camadas de origem dos materiais, apenas sendo possível a tentativa de uma reconstrução horizontal da estratigrafia do sítio arqueológico.

A área em intervenção foi divida utilizando o método de Mortimer Wheeler, com a adaptação através da não criação de banquetas, com um total 16 quadrículas de $5 \times 5 \mathrm{~m}$, contabilizadas no sentido de este para oeste, e de sul para norte a partir do vértice SE da superfície interna, delimitada pelos muros da fachada do jardim (Guimarães, Silva, 2017, p. 128o; Bargão, Ferreira e Silva, 2017, p.1782).

$\mathrm{Na}$ sequência desta intervenção, foram detetadas duas habitações distintas, uma escavada na sua quase totalidade, correspondendo esta às quadrículas 1 a 12; e a segunda, ás quadriculas 13 a 16.

Estas habitações terão sucumbido no terramoto de 1 de Novembro de 1755, conhecendo-se pelos trabalhos de Ferreira de Andrade na década de 40 do século XX, referentes à freguesia de $\mathrm{S}$. Cristóvão, que a primeira habitação estaria associada a D. Luís de Portugal (Andrade, 1946).

$O$ contexto em estudo é respeitante às condutas que se encontram na casa de D. Luís de Portugal, correspondendo estas às quadrículas 3,4 e 8 , que se inserem nas salas 3 e 6 da habitação 1 e ao muro Norte da sala 2, que separa o pátio da habitação e a sala 5 , tendo os materiais em estudo sido recolhidos integrando a argamassa que constitui o muro, que será datado, no mínimo, do $1^{\circ}$ quartel do século XVI, dados os materiais que compõem o contexto.

As condutas intervencionadas foram divididas em 3 partes, com a ligação através de caixas, correspondendo os materiais presentes no seu interior ao progressivo enchimento das mesmas, tendo sido recolhido um conjunto de espólio composto por, nomeadamente, cerâmica comum de barro vermelho; porcelana da dinastia Ming, do reinado Wanli; e faiança portuguesa. 


\section{O CONTEXTO DAS CONDUTAS}

O conjunto estudado, não correspondendo à totalidade dos materiais exumados nas condutas, é constituído por um total de 272 fragmentos de faiança portuguesa, sendo de realçar a ausência de qualquer espólio importado, com excepção de porcelana.

São possíveis de distinguir dois momentos do entulhamento da conduta, sendo a $1^{\underline{a}}$ fase da quadrícula 3 e 8 , e a $2^{\underline{a}}$ fase apenas na quadrícula 3 , sendo que a parte da conduta que se encontra na quadrícula 4 não apresenta qualquer espólio de faiança, o qual aparenta concentrar-se junto às caixas de junção da canalização.

As formas presentes correspondem maioritariamente à forma do prato, sendo que dentro desse grupo a forma do prato de bordo em aba, corresponde, aquando da análise do número mínimo de indivíduos geral do conjunto, a $24 \%$ dos NMI, num total de $58 \%$ de pratos. Encontram-se presentes também as formas de Covilhete (12\%), Taça (10\%) e Taça troncocónica (19\%) (Ver tabela 1).

Não foi possível determinar a que tipo de forma pertencem 149 fragmentos dos 272 em estudo, devido a estes se encontrarem em mau estado de conservação, não apresentando qualquer esmalte, ou estando muito fragmentados, não possibilitando mais nenhuma classificação para além de se determinar se se trata de bordo, fundo ou bojo.

As faianças recolhidas no contexto das condutas caracterizam-se por serem de fabrico regional, isto é, de Lisboa, com predomínio (91,18\%) das pastas de coloração amarela/creme (2.5Y 8/6), surgindo em minoria $(8,82 \%)$ pastas de coloração avermelhada (1oR 6/8), com apenas 24 fragmentos. As pastas amarelas possuem, na sua maioria um acabamento com esmalte de cor branca ( 5 YR 8/1), enquanto as pastas de coloração avermelhada são na sua maioria detentoras de um acabamento em esmalte verde (5YR 7/8) ou com uma tonalidade de transição entre verde e branco (5Y 8/2).

As pastas amarelas caracterizam-se por serem relativamente compactas, com textura moderadamente regular e reduzida resistência, com elementos não plásticos (ENP) que se caracterizam pela presença em grande quantidade de quartzo ferruginoso de média dimensão, pouca moscovite e alguns, raros, elementos ferruginosos.

As pastas avermelhadas caracterizam-se por serem pastas compactas, de textura e fractura irregulares.
Em termos de composição dos seus elementos não plásticos (ENP) partilha uma matriz comum com as pastas amarelas, notando-se apenas a adição de algum quartzo hialino de pequena/média dimensão. É de apontar que no interior do esmalte verde de acabamento, este apresenta também alguns quartzos ferruginosos embutidos em si, não sendo claro se fazem parte da superfície da pasta ou de constituintes do esmalte.

Quanto aos esmaltes, estes apresentam uma espessura muito fina, nunca excedendo os $0,5 \mathrm{~mm}$ de espessura.

Nas formas cujo esmalte é verde (pratos), ou de tonalidade verde (taças), estas nunca apresentam decoração, quer externamente, quer internamente. Estas faianças apresentam-se como as de cronologia mais recuada no contexto, enquadrando-se cronologicamente nos finais do século XVI e princípios do século XVII (Sebastian, 2010, p. 137).

Quanto às formas cerâmicas representadas no conjunto, destaca-se a por nós designada como prato de aba, para o qual possuímos somente um fragmento de perfil completo. Esta forma caracteriza-se por possuir um fundo em ônfalo, parede extrovertida em ângulo de cerca de $45^{\circ}$, com uma carena pronunciada na superfície externa, onde a orientação da parede verticaliza, terminando num bordo em aba, de forma côncava e tendência horizontal. Característica desta forma é ainda o esmalte esverdeado e as pastas avermelhadas, existindo, no entanto, alguns exemplares que possuem pasta amarela e um esmalte branco de muito boa qualidade, por vezes ainda com alguma tonalidade verde, denotando a transição para as produções canónicas Lisboetas.

Dentro da forma do prato, distinguiu-se ainda a forma do prato médio, que consideramos caracterizar-se por um bordo extrovertido, com uma secção côncava na transição entre o seu fundo e o bordo, apresentando internamente uma carena ligeiramente pronunciada na transição com o bordo. Esta forma apresenta ainda um pé em anel, que pode ser mais ou menos pronunciado. Apenas se optou por esta classificação aquando da presença de um perfil completo, situação que se verificou com o surgimento de dois pratos em muito bom estado de conservação, incluindo iconografia, a qual se distingue pela sua individualidade no conjunto.

A iconografia presente nestes dois exemplares de prato, remete, num dos casos para os temas barrocos, com a representação de um putti como tema 
central, havendo junto ao bordo uma inscrição em vináceo, ainda que, devido à fragmentação, não seja possível de interpretar. O outro prato, que se apresenta praticamente completo, e cuja forma não é completamente redonda, assemelhando-se a uma forma oval, é decorado com azul cobalto e amarelo, com motivos decorativos que não foram possíveis de precisar, ainda que a hipótese mais plausível seja a de motivos vegetalistas, à semelhança do ocorre na face externa, tendo este estilo decorativo uma cronologia de cerca de meados do século XVII.

No respeitante aos pratos fundos, considerou-se aqueles que possuindo o perfil completo, apresentam uma verticalidade entre $90^{\circ}$ e $70^{\circ}$ da parede, desde o fundo até ao bordo, sendo de difícil distinção uma área de transição clara entre o fundo e o bordo, contrariamente ao que ocorre no prato de aba e no prato médio. A decoração destas formas caracteriza-se por uma ou duas linhas a azul cobalto no interior junto à extremidade do bordo, e uma ou duas circunferências concêntricas no fundo, também em azul cobalto, podendo, na maioria dos casos, possuir uma decoração fitomórfica ou de inspiração oriental no interior do centro do fundo.

O prato covo carateriza-se pelo bordo côncavo e extrovertido, não existindo distinção entre a caleira do prato e o fundo, sendo somente uma só parte de forma hemisférica.

A forma de covilhete caracteriza-se por possuir um fundo plano, pé em anel, e uma parede muito verticalizada, com diâmetros de bordo enquadráveis entre os 13 e os 16 centímetros. Estas não possuem qualquer decoração, ou tendo será somente na superfície externa, com motivos barrocos, em arranhões e pêssegos, podendo possuir uma linha no interior, junto ao bordo, em manganês ou em azul cobalto.

A forma da taça caracteriza-se por ser hemisférica e por ter um diâmetro de bordo enquadrável entre 1o e 16 centímetros, com um bordo extrovertido, ligeiramente espessado externamente, e fundo em pé de anel. Estas formas apresentam-se como uma das mais representadas nas produções de esmalte verde e pasta avermelhada, nunca possuindo qualquer decoração nesse acabamento. Em esmalte branco, apresentam somente decoração em azul sobre branco, sem motivos compósitos.

A última forma identificada é a taça troncocónica, na qual considerámos as formas de grande dimensão, de fundo plano ou com tendência a descair para o plano do pé junto ao centro, parede de tendên- cia extrovertida, com um bordo espessado externamente, passível de ser considerado como lábio. Estas formas apresentam uma elaborada decoração em azul cobalto no seu interior, e apenas algumas linhas, que nos sugerem motivos vegetalistas, no exterior. Quanto ao seu pé, este não é marcadamente um pé de anel, no entanto, sem deixar de se destacar do fundo.

Dos materiais abordados, os únicos que não forneceram nenhuma forma relativamente bem preservada, apresentando o conjunto um elevado estado de fragmentação, foram as faianças de azul sobre azul, razão pela qual existe a possibilidade de um dos fragmentos poder ter possuído decoração a amarelo, mas sem certezas devido à sua fragmentação.

Quanto ao enquadramento cronológico do conjunto, este situa-se entre os finais do século XVI/princípios do século XVII ( $\mathrm{I}^{\mathrm{a}}$ fase), com as primeiras produções de faiança portuguesa, e os meados do século XVIII ( $2^{\underline{a}}$ fase), com as decorações em arranhões e pêssegos e os motivos fitomórficos simples (Gomes, Casimiro e Gonçalves, 2012, p.107).

Quanto à interpretação cronológica passível de ser efectuada a partir dos materiais, podemos afirmar, com certezas que estes correspondem a um progressivo processo de entulhamento e desativação das estruturas.

Assim, a primeira fase de entulhamento, enquadra-se entre o final do século XVI e a primeira metade do século XVII, de onde se destacam algumas camadas. Posto isto, observamos na quadricula $3 \mathrm{AB}$ - camada 42 , a presença de carena de prato de aba, sem decoração, com pasta amarela e cor branca com tom verde no exterior. Observa-se igualmente outro fragmento, agora um bordo, que se insere nas mesmas especificações que o fragmento suprarreferido. Propõe-se a cronologia centrada em torno a finais do século $\mathrm{XVI} /$ inicio do século XVII.

Já na camada 42 A foi exumado um fragmento correspondente a um prato de aba de tonalidade verde, com pasta avermelhada. Tendo em conta as informações expostas sobre o fragmento exumado é possível datar esta camada a finais do século XVI (Sebastian, 2010).

Na quadricula 8 - camada 7 , surge o fragmento de perfil completo de prato com decoração a azul e amarelo. Foi exumado também o fragmento de bordo de um prato de aba com esmalte a branco. E salientamos ainda um fragmento de um fundo em ônfalo também de prato de aba. Com base nas evidências, e 
em particular na decoração a amarelo e azul, apontamos a um momento próximo de meados do século XVII (Casimiro e Sequeira, 216 p. 263).

A segunda fase do processo de entulhamento e abandono das condutas, que apenas está documentada na quadrícula 3, na parte respeitante às condutas 2 e 3 , está datada entre a $2^{2}$ - metade do século XVII e o início do século XVIII.

Esta datação é corroborada pela recolha, na conduta 2 - camada 41, de três fragmentos de prato com decoração simples em azul; um do bojo de tigela sem decoração e um fragmento de prato com decoração a azul sobre azul e amarelo (berretino). Exposto isto, é possível datar a camada a meados do século XVII/XVIII.

Já para a conduta 3, na camada 23 c), foi exumado um fragmento de bordo de prato, que apresenta decoração em vináceo e azul de tema barroco com pêssegos. Surge também um fragmento de fundo de prato, cuja decoração apresenta motivos vegetalista a azul e vináceo da faixa barroca. Referimos por último um fragmento de bordo pertencente a uma taça decorado a azul e branco. Face ao exposto é possível sugerir a datação da camada entre o final do século XVII e o início do século XVIII. (Gomes, Casimiro, Gonçalves, 2012. p. 107).

Assim, e tendo em consideração que a adição de letras à numeração das camadas corresponde a extensões das camadas, podemos afirmar que o entulhamento da conduta 3 corresponde na sua fase mais antiga à camada 42 (entulhando então também parte da conduta 2), datada de finais do século XVI, seguida de novo entulhamento (camada 41) enquadrável já no século XVII, provavelmente durante o $1^{\circ}$ quartel do século XVII.

A conduta 2 terá tido também o seu primeiro entulhamento nos finais do século XVI, seguida de novo entulhamento já em pleno século XVII e no inicio do século XVIII.

$\mathrm{Na}$ sala 3, as condutas são colmatadas pela camada 23 e suas extensões, datadas do século XVIII.

Quanto à caixa N, ou seja, a transição entre a conduta 2 e a conduta 1, esta é datável, na sua colmatação, ao inicio do século XVII, já que as formas presentes assim o comprovam.

Apenas a conduta 1 não apresenta qualquer espólio de faiança, pelo que não é possível atestar o momento do seu abandono, no entanto, este deverá ser contemporâneo à caixa N, ou seja, inicio do século XVII. Assim, levantam-se algumas questões quanto à cro- nologia avançada por Luís Sebastian (2010) para as produções de esmalte verde, podendo, a nosso ver, ser remetido para meados do século XVI, ao invés do final da centúria. Quanto ao final das produções de pasta vermelha e esmalte verde, o espólio aparenta apontar o seu desaparecimento nos meados do século XVII, quando se encontra ausente e as suas formas são substituídas por iguais em esmalte branco, mantendo, ainda as mesmas pastas vermelhas inalteradas e em convivência com pratos com as pastas amarelas e formas do século XVII/XVIII.

\section{CONTEXTO DO MURO NORTE DA SALA 2}

A construção do edifício, integrado inicialmente nas casas de D. Catarina, e posteriormente propriedade de D. Luís de Portugal (Bargão, Ferreira e Silva, 2017, p. 1788; Andrade, 1946), terá resultado de uma remodelação profunda do espaço previamente existente, com a já analisada desactivação do cano baixo-medieval e a edificação de uma residência destinada a ocupantes da alta burguesia ou nobreza, podendo ser mencionada a riqueza do edifício através da sua decoração profusa com azulejos, dos quais se destacam as importações, que permitem situar a edificação ou remodelação do espaço em torno à década de 1520 (Bargão, Ferreira e Silva, 2017, p. 1787-1788).

Foi, no entanto, identificado no muro Norte da sala 2 um contexto referente à construção da habitação, onde se integraram materiais arqueológicos nas argamassas, podendo por tal ser atribuída uma cronologia entre os meados do século XVI e o inicio do século XVII que, ainda que correspondendo a um pequeno conjunto, encontram representadas produções italianas, alemãs (Westerwald) e de Manizes/Paterna. É de realçar que, sem contexto claro, surgem mais alguns fragmentos desta cronologia entre os materiais do contexto de 1755 , sendo que pelo estado de conservação dos fragmentos, é sugerido que se tratem de fragmentos provenientes de perturbações posteriores nos contextos mais antigos, com produções Valencianas e Sevilhanas, bem como, de Majólica.

O conjunto resultou, após analise estatística (tabela 1), na determinação de um número mínimo de indivíduos (NMI) de 14, sendo que, apenas 42,86\% do total tem proveniência nacional, com os fabricos enquadrando-se nas produções características de Lisboa, com esmalte de coloração branca. 
A nível decorativo, a faiança portuguesa caracteriza-se pela ausência de motivos decorativos, sendo de realçar a predominância das formas dos pratos e das taças, e a representação por apenas um individuo da forma de covilhete, a qual apresenta profundo desgaste do esmalte no bordo.

No respeitante às produções europeias realça-se sobretudo as produções italianas, com $35,71 \%$ do total de indivíduos.

Aqui poderá ser destacada supremacia das produções de majólica, com dois indivíduos de origem indeterminada, e um das fábricas de Montelupo, este com decoração policroma com azul, verde e amarelo sobre fundo branco.

De realçar que as produções de Montelupo destacam-se entre os finais do séc. XV e a primeira metade do séc. XVI, beneficiando de um grande porto, permitindo a difusão da cerâmica dentro e fora da península itálica (Barradas e Silva, 2017, p.1678), daí que esteja atestado com alguma abundância nos contextos portugueses e Lisboetas, realçando-se aqui as exumadas em Carnide, no largo do Coreto e no largo do Jogo da Bola, onde se recolheram fragmentos de Montelupo que apresentavam decoração a fogila bleu, que se manifesta pelos motivos vegetalistas a azul de grandes dimensões, a decoração nastri e decoração beretino a azul sobre azul. (Casimiro, Boavida e Moço, 2015, p. 61; Felício, Sousa, Guimarães e Gadanho, 2017, p. 1809-1820).

Estas produções combinam dois fragmentos de decoração policromática (a nastri spezzati,) um com decoração de estilo berretino, e um com decoração geométrica no fundo, inserindo-se proximamente do estilo orientale evoluto. $\mathrm{O}$ estilo a nastri spezzati (1550-16oo), é um motivo exclusivo de formas abertas que consiste em bandas entrelaçadas e cortadas, realizadas a azul e outras cores muito vivas, as quais rodeiam um tema central, que poderia ser uma espécie de flor ou de estrela; enquanto o estilo orientale evoluto (1550-159o), é constituído por uma rede de losangos e linhas curvas a azul, preenchidos por elementos estilizados realizados em cores vivas (Cavaco e Covaneiro, 2017, p. 208).

O estilo berretino poderá ser associado às oficinas de Faenza e Veneza que, no séc. XVI, desenvolveram o Stile Bello, composto por elementos monocromáticos azuis com pinceladas brancas sobre um fundo azul ou azul-acinzentado para o que se designa de berretino, o qual é inspirado na porcelana chinesa, sendo caracterizado pela gradação de cores dentro do espetro azul e manifesta-se pelo carater simplicista e vegetalista da decoração. (Farris e Ferrarese, 1969, p. 206).

Nas produções italianas foi ainda recolhido um bordo possível de identificar como uma produção Lígure, o qual se insere igualmente no estilo berretino, ainda que o esmalte se encontre mal preservado e não permita uma leitura profunda do motivo decorativo.

Menos representadas, com apenas 7,14\% do total de indivíduos, encontramos as produções de Manizes ou Paterna, as quais se encontram muito fragmentadas, apenas podendo ser consideradas como um individuo, apresentando a habitual ausência de decoração, com um esmalte brilhante e resistente de cor madrepérola.

Quanto às produções alemãs, no território nacional detectam-se as produções provenientes da região do Reno, destacando-se as peças do tipo Bellarmine. Estas, são jarras que se apresentam com a foram de um homem, sendo uma alusão ao cardeal jesuíta Roberto Bellarmino (Cavaco, Covaneiro, 2017, p. 210). No contexto dos jardins do Palácio dos Condes de Penafiel surge somente um fragmento de bojo desta produção em grés, com parte de decoração com uma bolota. Estas formas de grés, foram produzidas entre o séc. XVI e o séc. XVIII, sendo que estas representam uma inovação tecnológica, uma vez que a adição de sal durante a cozedura gera superfícies vitrificadas com aspeto acetinado, mais brilhantes e resistentes (Cavaco, Covaneiro, 2017, p. 210).

A representatividade das produções de Majólica no contexto (43\%), que em conjunto com a faiança portuguesa perfazem a quase totalidade do espólio, permitem apontar para a cronologia já sugerida entre meados do século XVI e o inicio do século XVII, sendo que, a nosso entender, este contexto deverá ter uma conexão com o contexto das condutas e os azulejos exumados nesta intervenção (Bargão, Ferreira e Silva, 2017), aproximando-se a cronologia de meados do século XVI, podendo inclusive ser anterior à data de 1550 apontada para as decorações de Majólica (Cavaco e Covaneiro, 2017, p.208; Farris e Ferrarese, 1969, p. 206).

\section{CONCLUSÕES}

Da escavação efetuada em 1992-1993, nos jardins do PPJ, nos contextos em análise, foram assim recolhidos um total de 294 fragmentos, dos quais se determinou um número mínimo de indivíduos total de 
97, que remetem para uma cronologia entre o século XVI e XVII.

Esta realidade observada é coeva com os dados já anteriormente fornecidos pelos 866 azulejos hispano-mouriscos, de onde se destacam dois exemplares utilizando a técnica de corda-seca, um alicatado, e os restantes, com a técnica "de aresta" ou "cuenca", os quais foram associados à decoração que revestiria os andares superiores das "casas de dona Catarina", com posteridade a 1524, e cuja produção poderia ser oriunda das oficinas de Triana de Juan ou Diego Polido, na década de 1520 (Bargão, Ferreira e Silva, 2017, p. 1786-1788).

Assim, de acordo com os resultados obtidos, confirmar-se a edificação das "casas de Dona Catarina" nas primeiras décadas do século XVI, bem como a anterioridade da conduta, a qual já se encontraria naquele espaço no século XV, parecendo ocorrer um aproveitamento da sua existência aquando do planeamento do edifício, com o cuidado da não obstrução com muro das caixas de junção, as quais foram, em função das evidências materiais, tidas pelos habitantes como áreas de descarte para os lixos do quotidiano.

O numeroso espólio aqui analisado, com destaque para as condutas, espelha o quotidiano do lugar, atestando desde cedo o que se poderá considerar como um relativamente elevado poder de compra por parte dos residentes, com o consumo de faiança portuguesa a seguir todas as suas transformações formais e estilísticas na diacronia, denotando-se uma tendência para a aquisição dos materiais mais recentes, situação que poderá espelhar um fenómeno do seguimento de modas, e por tal permite inferir quanto ao status dos que habitavam nas "casas de Dona Catarina”.

Por fim, ainda que o contexto do muro não permita compreender em maior profundidade o que seria aquele espaço antes da edificação da habitação, em torno à década de 1620, o espólio permite já inferir que naquela área existiriam habitantes com elevado poder económico que consumiam os bens importados de Espanha, Itália e Alemanha, ainda que pareça que nesta área o consumo destes bens, sobretudo da majólica, pareça ser mais tardio e menos expressivo que em outras zonas de Lisboa.

\section{BIBLIOGRAFIA}

ANDRADE, Ferreira de (1946) - A freguesia de S. Cristóvão. Volume I e II. Lisboa: Câmara Municipal de Lisboa.

ARCELIN, P.; TUFFREAU-LIBRE M., ed. (1998) - Protocole de quantification des céramiques. In La quantification des céramiques. Conditions et protocole, Actas da mesa redonda de Bibracte. Glux-en-Glenne: Centre archéologique européen, pp.141-157.

BARGÃO, André; FERREIRA, Sara; SILVA, Rodrigo Banha da (2017) - Policromias e padrões: azulejos "de aresta" e "de corda-seca" do Palácio dos Condes de Penafiel, Lisboa (séculos XV-XVI). In Arqueologia em Portugal - Estado da Questão, Lisboa: Associação dos Arqueólogos Portugueses, pp. 1781-1794.

BARRADAS, Ana Isabel; SILVA, Rodrigo Banha da (2017) - Cerâmicas Quinhentistas vidradas de um poço Medieval da Praça da Figueira (Lisboa). In Arqueologia em Portugal - Estado da Questão. Lisboa: Associação dos Arqueólogos Portugueses, pp. 1691-1702.

CASIMIRO, Tânia Manuel; BOAVIDA, Carlos; MOÇO, Ana (2015) - Louça "de fora" em Carnide (1550-1562) Estudo do consumo de cerâmica importada. In I Encontro de Arqueologia de Lisboa: Uma Cidade em Escavação. Lisboa: Centro de Arqueologia de Lisboa/Departamento de Património Cultural/Direção Municipal de Cultura/Câmara Municipal de Lisboa/ (CAL/DPC/DMC/CML), pp. 57-67.

CASIMIRO, Tânia; SEQUEIRA, João (2016) - Faiança Portuguesa dos séculos XVI-XVIII recuperada no Tejo. Cira Arqueologia. Vila Franca de Xira. Volume 5, pp. 260-273.

CAVACO, Sandra; COVANEIRO, Jaquelina (2017) - Evidências das relações comerciais do porto de Tavira através da cerâmica. Scientia Antiquitatis. Évora. Volume 1, no 2, pp. 195-218.

FARRIS, G; FERRARESE, V. A. (1969) - Contributo alla conoscenza della tipologia e della stilistica della maiolica ligure del XVI secolo. Atti della Società Ligure de Storia Patria. Génova, pp. 187-221.

FELÍCIO, Catarina; SOUSA, Filipe; GUIMARÃES, Raquel; GADANHO, André (2017) - A cerâmica Italiana dos séculos XV e XVI do Largo do Jogo da Bola em Carnide, Lisboa. In Arqueologia em Portugal - Estado da Questão. Lisboa: Associação dos Arqueólogos Portugueses, pp. 18o9-1820.

GOMES, Mário Varela; CASIMIRO, Tânia Manuel; GONÇALVES, Joana (2012) - Espólio do Naufrágio da Ponta do Leme Velho (Ilha do Sal, Cabo Verde): Contributo para a Arqueologia da Expansão. Lisboa: Instituto de Arqueologia e Paleociências.

GUIMARÃES, Raquel; SILVA, Rodrigo Banha da (2017) Um contexto cerâmico e vítreo da primeira metade do séc. III d.C. do Palácio dos Condes de Penafiel (Lisboa). In Arqueologia em Portugal - Estado da Questão. Lisboa: Associação dos Arqueólogos Portugueses, pp. 1279-1292. 
HENRIQUES, José Pedro Vintém (2012) - Do Oriente para Ocidente: contributo para o conhecimento da porcelana chinesa nos quotidianos de época moderna. Estudo de três contextos arqueológicos de Lisboa. Velhos e Novos Mundos. Estudos de Arqueologia Moderna. Lisboa: Centro de História de Além-Mar. Volume 2, pp. 919-932.

MUNSELL, Richard (1994) - Soil Color Charts. New widson: Kollmorgen Instruments, Macbeth Division.

SEBASTIAN, Luís Carlos Pereira (2010) - A produção oleira de faiança em Portugal (séculos XVI-XVIII). Tese de Doutoramento em História variante Arqueologia. Lisboa: Faculdade de Ciências Sociais e Humanas da Universidade Nova de Lisboa, pp. 91-516.

SILVA, Rodrigo Banha da; FERREIRA, Sara (2015) - Jarro. In Lisboa 1415 Ceuta. Uma história de duas cidades. Ceuta/ Lisboa: Ciudad Autónoma de Ceuta/Câmara Municipal de Lisboa e Faculdade de Ciências Sociais e Humanas da Universidade Nova de Lisboa, p. 134.

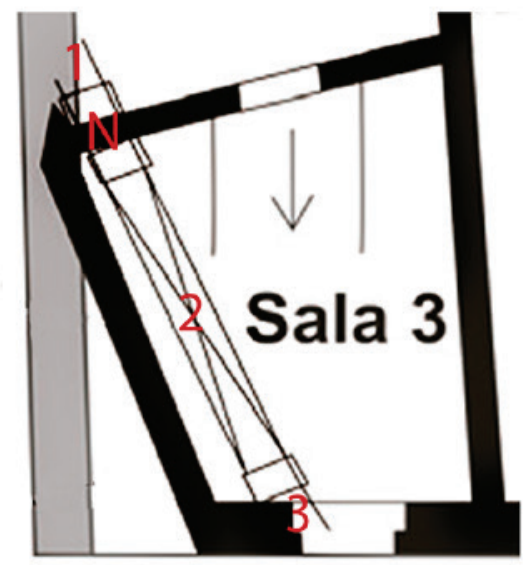

\section{1 - Conduta 1}

2 - Conduta 2

3 - Conduta 3

$\mathrm{N}$ - Caixa de junção $\mathrm{N}$ entre a conduta 1 e 2

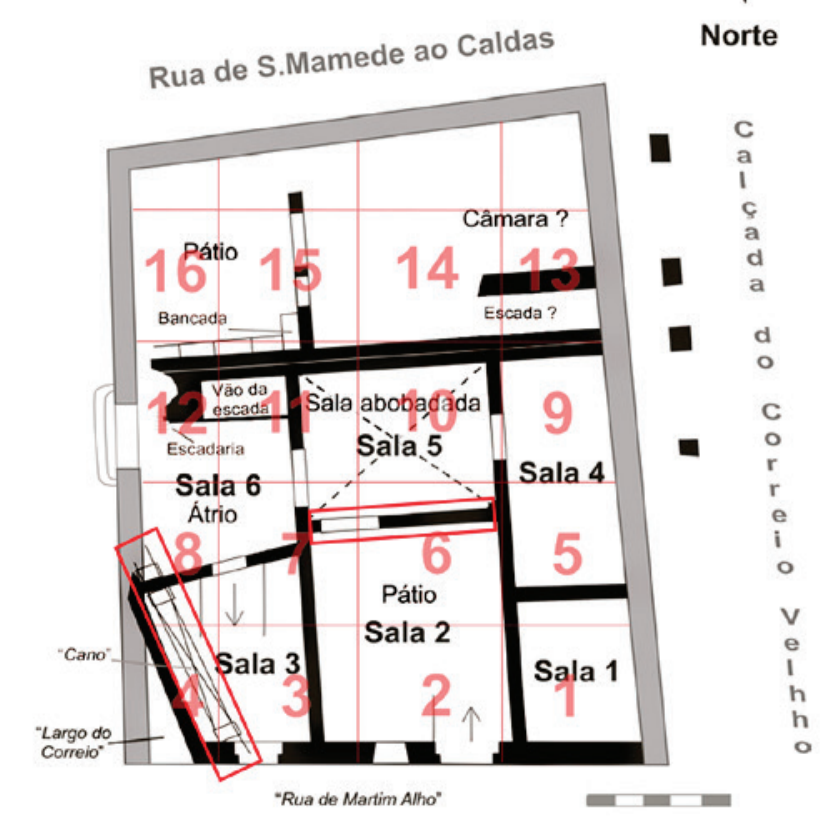

Figura 1 - Planta geral da intervenção de 1992-1993, estando assinalado com rectângulos vermelhos os contextos em análise. Adaptado de Bargão, Ferreira e Silva, 2017, p. 1791. 


\begin{tabular}{|c|c|c|c|c|c|}
\hline \multicolumn{6}{|c|}{ NMI Condutas 1-3 } \\
\hline Forma & № de fragmentos & Fragmento & № de fragmentos & NMI & \% NMI Prod. \\
\hline \multirow{2}{*}{ Covilhete } & \multirow{2}{*}{10} & Perfil Completo & 3 & \multirow{2}{*}{10} & \multirow{2}{*}{$12 \%$} \\
\hline & & Bordo & 7 & & \\
\hline \multirow{5}{*}{ Prato } & \multirow{5}{*}{45} & Perfil Completo & 2 & \multirow{5}{*}{20} & \multirow{5}{*}{$24 \%$} \\
\hline & & Bordo & 18 & & \\
\hline & & Fundo & 17 & & \\
\hline & & Bojo & 6 & & \\
\hline & & Carena & 2 & & \\
\hline \multirow{5}{*}{ Prato de aba } & \multirow{5}{*}{31} & Perfil Completo & 1 & \multirow{5}{*}{20} & \multirow{5}{*}{$24 \%$} \\
\hline & & Bordo & 19 & & \\
\hline & & Fundo & 5 & & \\
\hline & & Bojo & 3 & & \\
\hline & & Carena & 3 & & \\
\hline Prato médio & 4 & Perfil Completo & 4 & 4 & $5 \%$ \\
\hline Prato fundo & 3 & Perfil Completo & 3 & 3 & $4 \%$ \\
\hline Prato covo & 1 & Bordo & 1 & 1 & $1 \%$ \\
\hline \multirow{3}{*}{ Taça } & \multirow{3}{*}{10} & Perfil Completo & 1 & \multirow{3}{*}{8} & \multirow{3}{*}{$10 \%$} \\
\hline & & Bordo & 7 & & \\
\hline & & Fundo & 2 & & \\
\hline \multirow{4}{*}{ Tigela } & \multirow{4}{*}{19} & Perfil Completo & 4 & \multirow{4}{*}{16} & \multirow{4}{*}{$19 \%$} \\
\hline & & Bordo & 12 & & \\
\hline & & Fundo & 2 & & \\
\hline & & Bojo & 1 & & \\
\hline \multirow{3}{*}{ Indeterminada } & \multirow{3}{*}{149} & Bordo & 19 & \multirow{3}{*}{1} & \multirow{3}{*}{$1 \%$} \\
\hline & & Fundo & 26 & & \\
\hline & & Bojo & 104 & & \\
\hline Total & 272 & & 272 & 83 & $100 \%$ \\
\hline
\end{tabular}

Tabela 1 - Contabilização do número mínimo de indivíduos total do conjunto exumado nas condutas.

\begin{tabular}{|c|c|c|c|c|c|}
\hline \multicolumn{6}{|c|}{$\begin{array}{c}\text { Quadrícula 6/7 } \\
\text { Muro Norte da Sala } 2\end{array}$} \\
\hline Fabrico & Forma & Fragmento & $\begin{array}{c}\text { № de } \\
\text { Fragmentos }\end{array}$ & NMI & $\% \mathrm{NMI} /$ Total \\
\hline \multirow{4}{*}{$\begin{array}{c}\text { Faiança } \\
\text { Portuguesa }\end{array}$} & Prato & $\begin{array}{c}\text { Bordo } \\
\text { Bojo }\end{array}$ & $\begin{array}{l}2 \\
1 \\
\end{array}$ & 2 & $14,29 \%$ \\
\hline & Covilhete & Bordo & 1 & 1 & $7,14 \%$ \\
\hline & Taça & $\begin{array}{l}\text { Bordo } \\
\text { Fundo }\end{array}$ & $\begin{array}{l}2 \\
1\end{array}$ & 2 & $14,29 \%$ \\
\hline & Indeterminada & Bordo & 1 & 1 & $7,14 \%$ \\
\hline Alemão & Belarmino & Bojo & 1 & 1 & $7,14 \%$ \\
\hline Manizes/Paterna & Taça & Carena & 2 & 1 & $7,14 \%$ \\
\hline \multirow{3}{*}{$\begin{array}{l}\text { Majólica (origem } \\
\text { indeterminada) }\end{array}$} & \multirow{3}{*}{ Indeterminada } & Bordo & 1 & \multirow{3}{*}{2} & \multirow{3}{*}{$14,29 \%$} \\
\hline & & Fundo & 2 & & \\
\hline & & Bojo & 1 & & \\
\hline \multirow{2}{*}{ Montelupo } & Prato & Fundo & 1 & 1 & $7,14 \%$ \\
\hline & Indeterminada & Fundo & 1 & 1 & $7,14 \%$ \\
\hline Ligúria & Prato & Bordo & 1 & 1 & $7,14 \%$ \\
\hline Indeterminado & Indeterminada & Bojo & 4 & 1 & $7,14 \%$ \\
\hline Total & & & 22 & 14 & $100,00 \%$ \\
\hline
\end{tabular}

Tabela 2 - Contabilização do número mínimo de indivíduos total do conjunto exumado no muro Norte da sala 2. 
Condutas
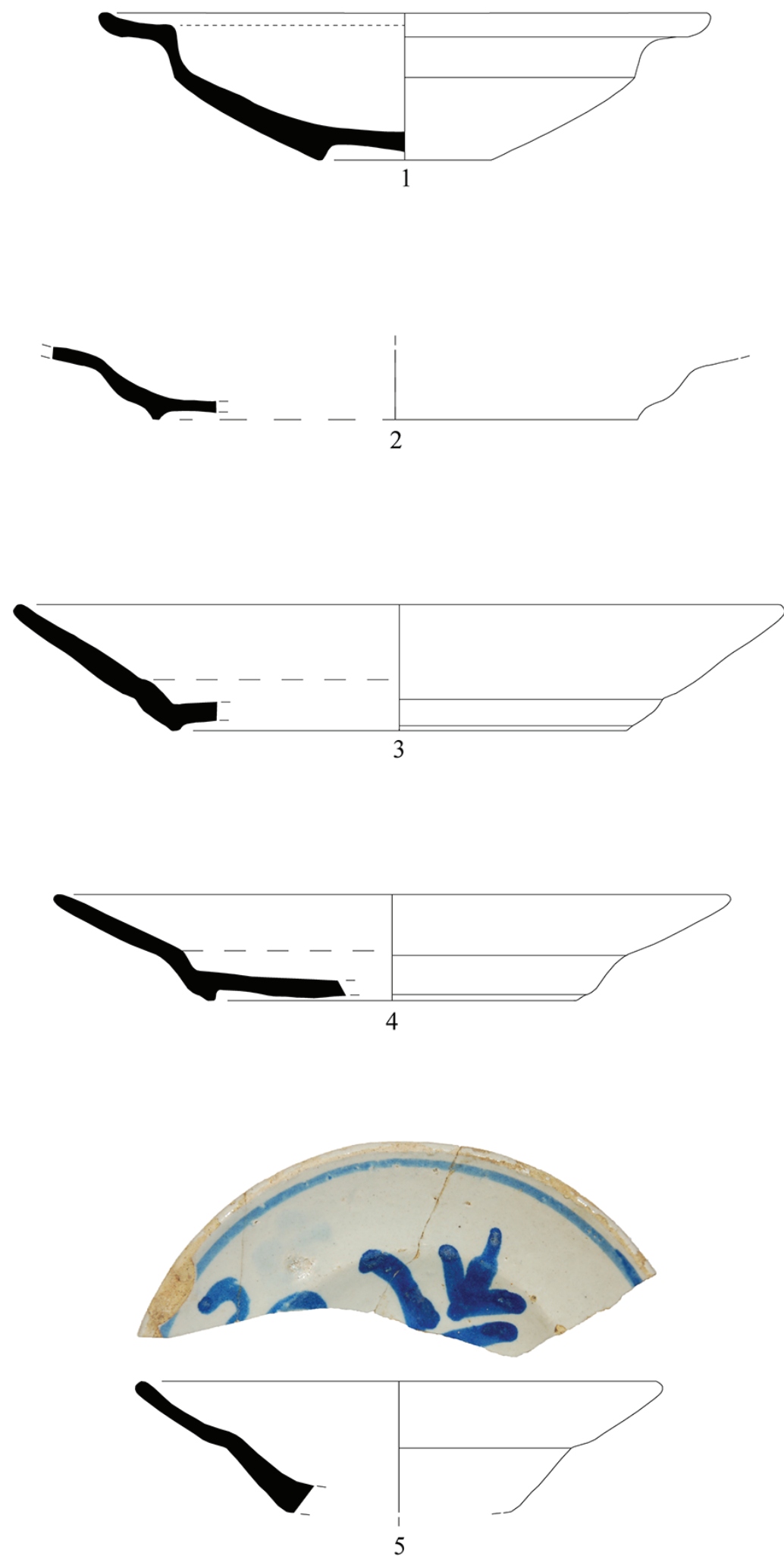

Escala 1:2

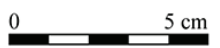

Figura 2 - Espólio de faiança portuguesa exumado nas condutas. 1 - prato de aba; 2-4 - pratos médios; 5 - prato covo. 

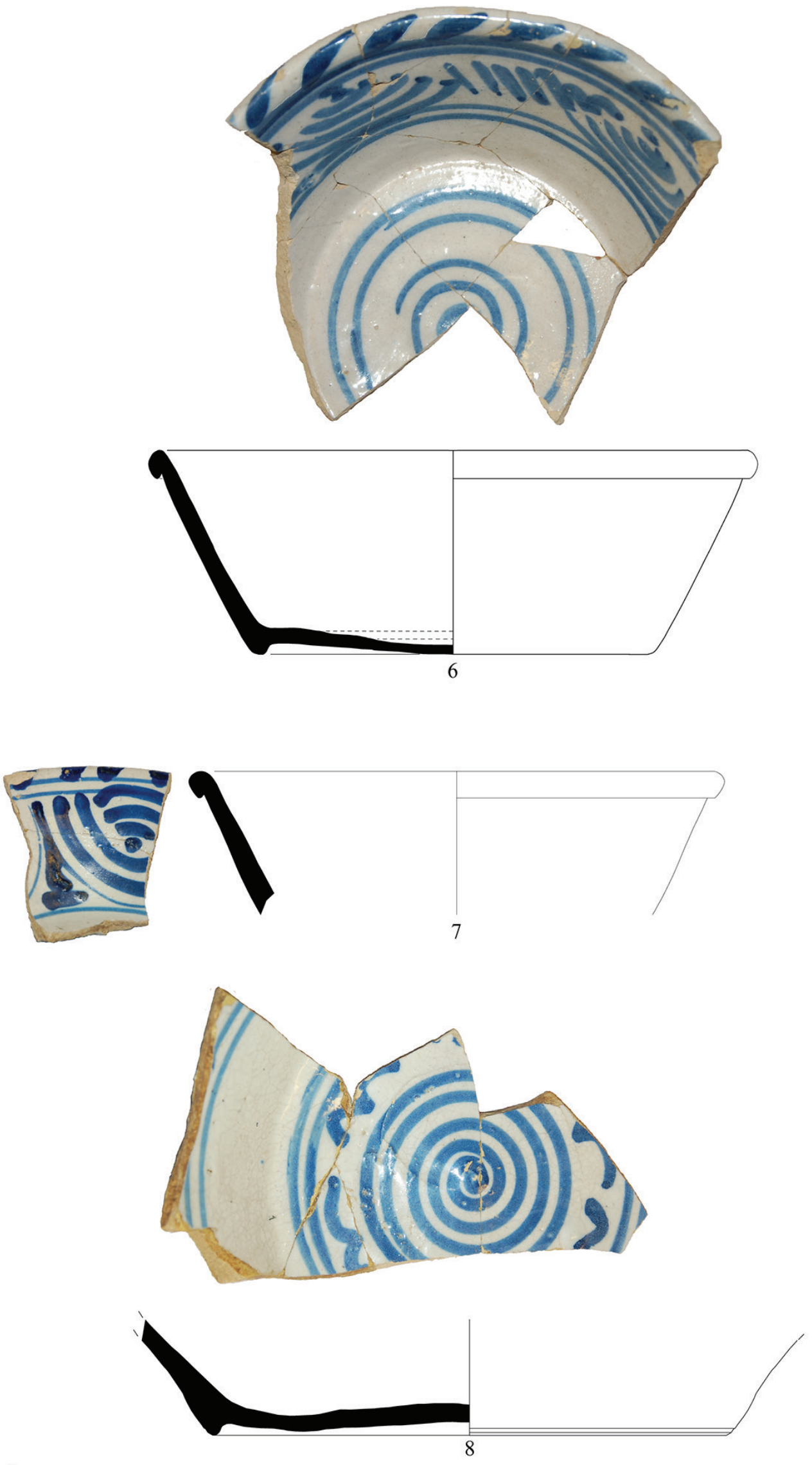

Escala 1:2

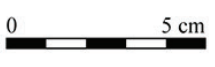

Figura 3 - Espólio de faiança portuguesa exumado nas condutas. 6-8 - Taça troncocónica com decoração em azul cobalto. 

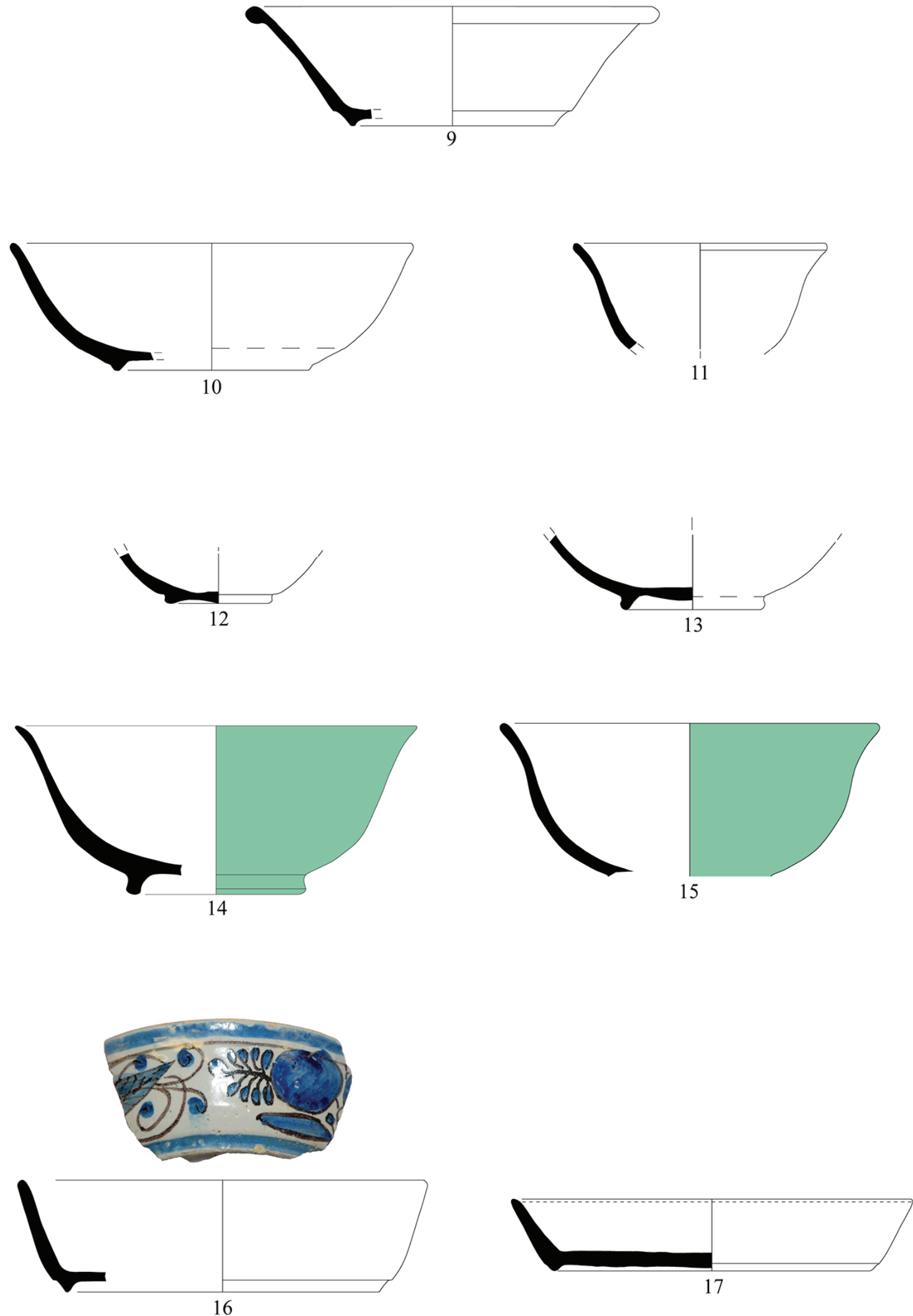

Escala 1:2

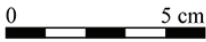

Figura 4-Espólio de faiança portuguesa exumado nas condutas. 9 - taça troncocónica; 10-13 - tigelas de esmalte branco; 14-15 - tigelas de esmalte verde; 16-17- covilhetes. 

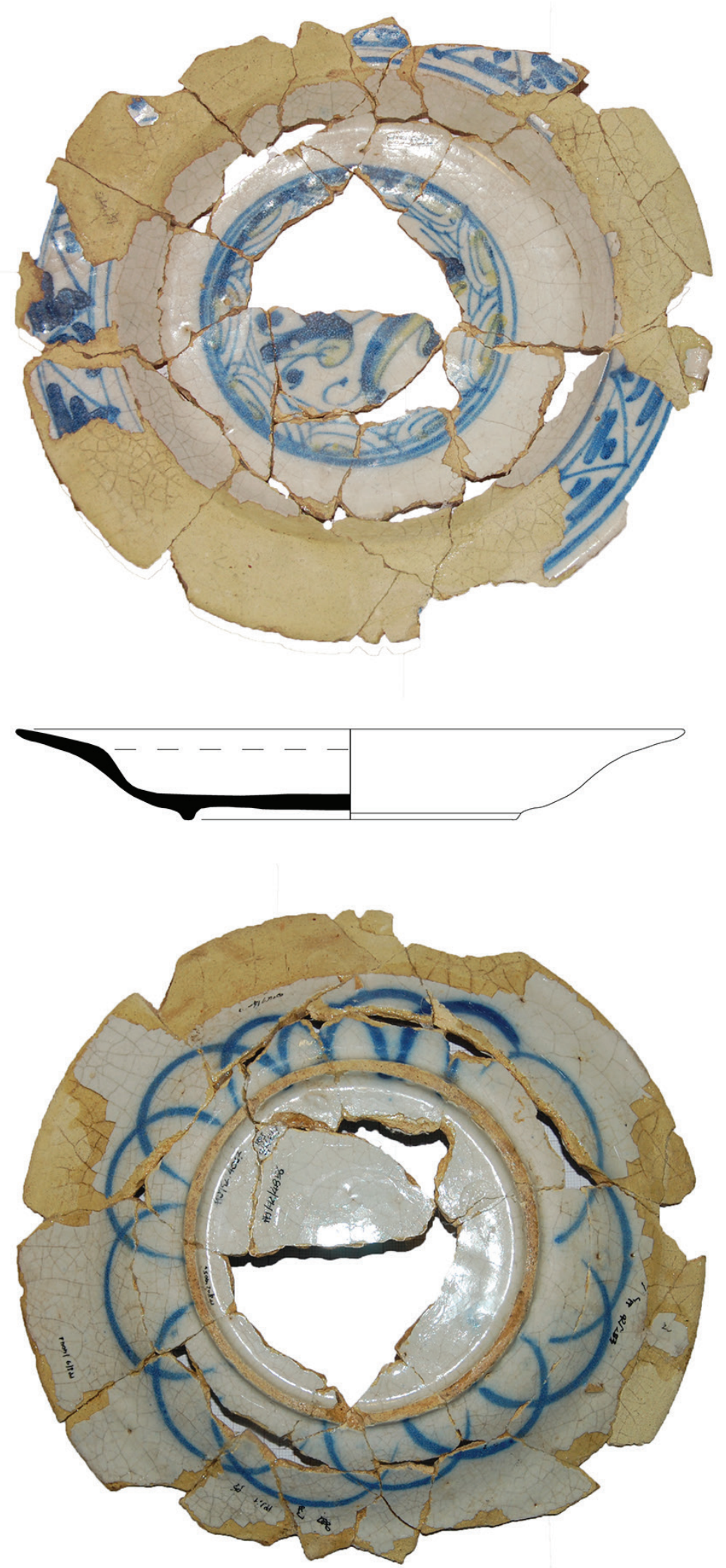

Figura 5-Espólio de faiança portuguesa exumado nas condutas. 18 - prato de motivos vegetalistas em azul cobalto e amarelo. 

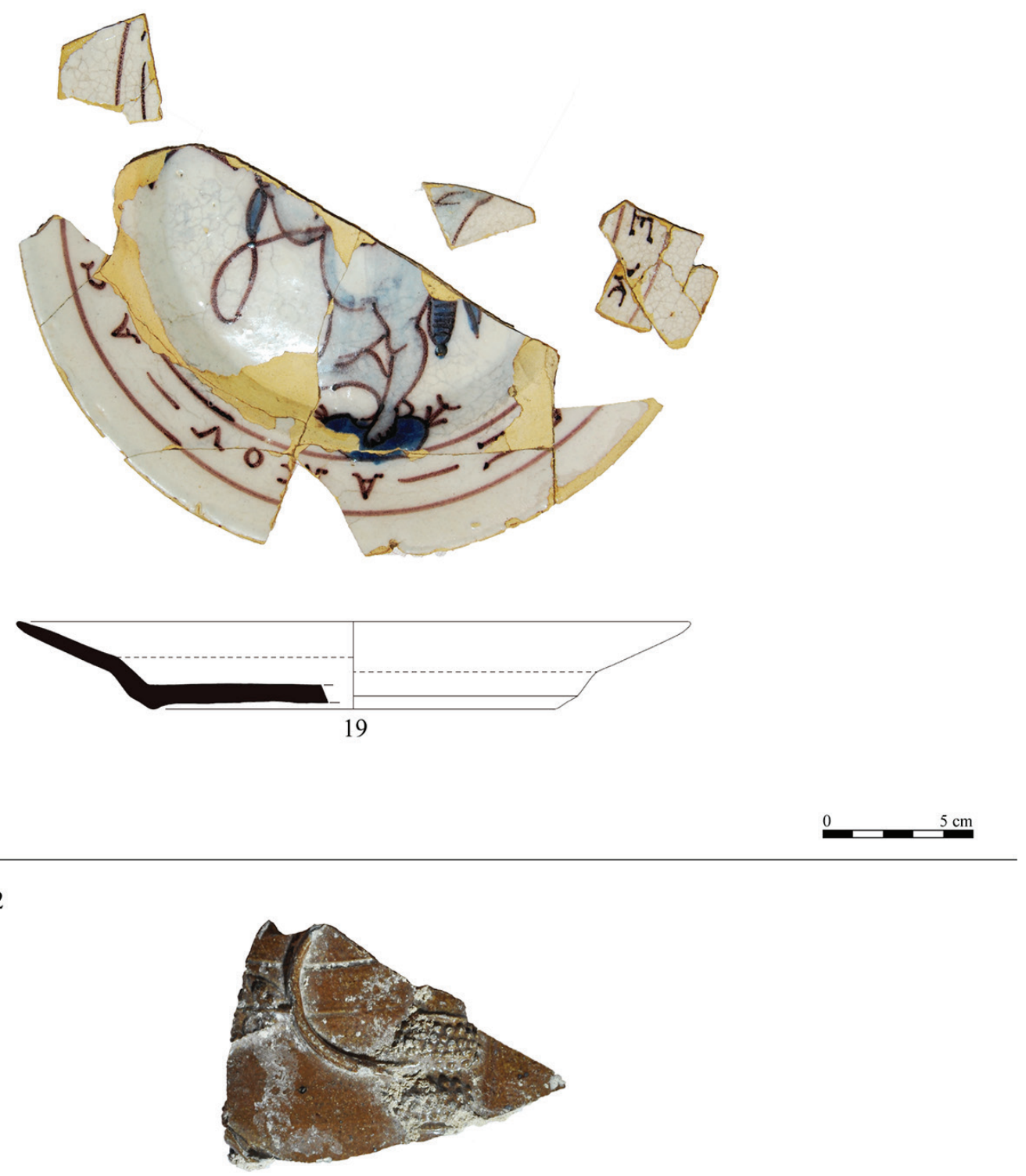

20

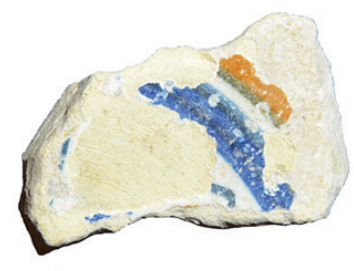

21

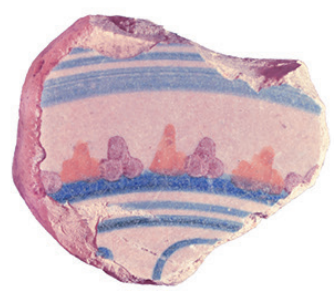

22

Escala $1: 1$

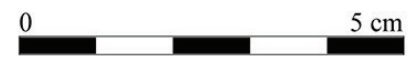

Figura 6 - Espólio de faiança portuguesa e europeia exumado nas condutas e muro Norte da Sala 2. 19 - prato com decoração barroca (putti); 20 - fragmento de Belarmino; 21-22 - fragmentos de majólica. 



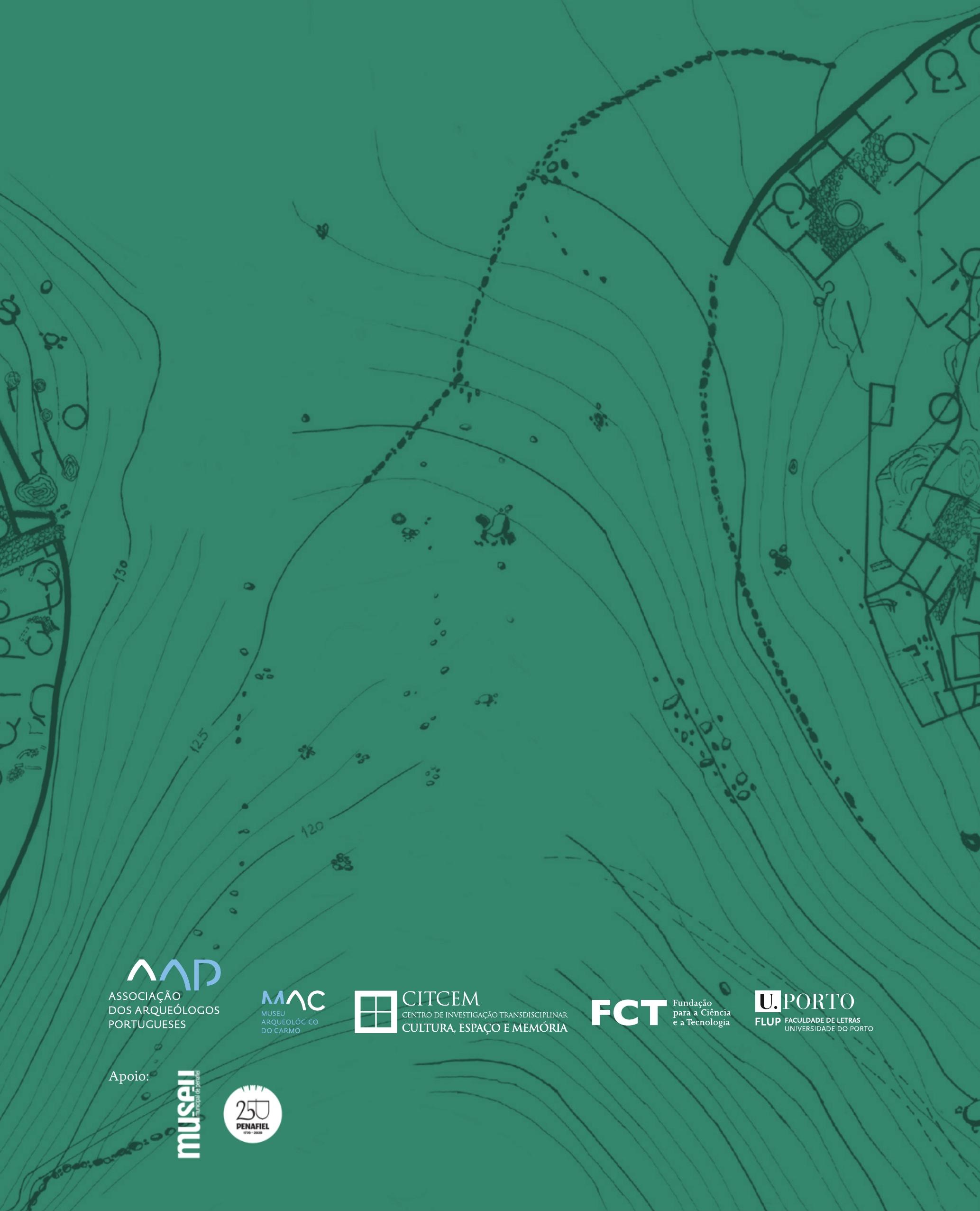

